W stużbie tradycji i odnowy liturgicznej. 50 lat Instytutu Liturgicznego w Krakowie (1968-2018), red. P. Nowakowski, J. Mieczkowski, Kraków 2019, s. 81-99.

ISBN 978-83-7438-849-8 (wersja drukowana), ISBN 978-83-7438-850-4 (wersja online) DOI:http://dx.doi.org/10.15633/9788374388504.08

Henryk Sławiński

Uniwersytet Papieski Jana Pawea II w Krakowie, Polska

ORCID: 0000-0003-4290-6743

\title{
Homiletyka akademicka w Instytucie Liturgicznym - początki i rozwój
}

Instytucje są tworzone przez ludzi. Zwłaszcza gdy chodzi o szkolnictwo wyższe, o doniosłości ośrodka decydują wybitni pracownicy. Tam, gdzie są twórczy myśliciele, tworzy się silny ośrodek. Jeśli chodzi o polską homiletykę akademicką, do najważniejszych jednostek należy niewątpliwie Instytut Liturgiczny na Uniwersytecie Papieskim Jana Pawła II. Przed 15 laty ukazało się kilka publikacji prezentujących wybrane aspekty działalności homiletycznej tego ośrodka ${ }^{1}$. Ponieważ w kolejnych latach dalej się on znakomicie rozwijał, warto przedstawić jego dokonania. Celem niniejszego opracowania jest więc omówienie genezy i rozwoju homiletyki akademickiej w Krakowie, a także aktualnej działalności homiletycznej naukowego ośrodka badawczo-dydaktycznego, jakim jest wspomniany

1 Por. J. Mieczkowski, Krakowski Instytut Liturgiczny, Kraków 2005, s. 243-244; W. Przyczyna, G. Siwek, Krakowska Szkoła Kaznodziejów jako odpowiedź na wyzwania czasów, w: Archidiecezja Krakowska na przełomie tysiacleci, red. S. Koperek i in., Kraków 2004, s. 537-544; H. Sławiński, Powstanie i rozwój Katedry Komunikacji Religijnej PAT, w: Introibo ad altare Dei. Księdzu Profesorowi Stefanowi Koperkowi CR z okazji 7o-lecia urodzin i 45-lecia kapłaństwa, red. S. Szczepaniec, J. Superson, J. Mieczkowski, Kraków 2008, s. 833-843. 
Instytut Liturgiczny. Ponieważ nie jest on jedynym ośrodkiem akademickim kształcącym homiletów polskich, poprzedzimy jego przedstawienie bardzo zwięzłą prezentacją innych tego typu jednostek w Polsce.

\section{Posoborowa homiletyka akademicka w Polsce}

Myśląc o homiletyce polskiej, trzeba zauważyć, że bezpośrednio po soborze watykańskim II jej najwybitniejszym przedstawicielem był ks. dr Marian Rzeszewski (1911-1982), który pracował w Wyższym Seminarium Duchownym we Włocławku². Kształcił on duszpasterzy, ale nie homiletów, czyli wykładowców homiletyki. Ci ostatni w latach siedemdziesiątych i osiemdziesiątych byli kształceni w dwóch liczących się ośrodkach naukowo-badawczych w Polsce: w Warszawie i w Lublinie.

W Akademii Teologii Katolickiej w Warszawie homiletykę wykładał ks. dr Leszek Kuc (1927-1986), a następnie ks. prof. dr hab. Antoni Lewek (1940-2010). Natomiast na Katolickim Uniwersytecie Lubelskim za kształcenie nowych pokoleń homiletów odpowiadał ks. doc. dr hab. Mieczysław Brzozowski (1933-1991), który w latach 1982-1991 był kierownikiem Katedry Homiletyki Instytutu Teologii Pastoralnej. Ksiądz prof. Lewek zajmował się posoborową odnową kaznodziejstwa, a ks. doc. Brzozowski historią kaznodziejstwa. Po śmierci ks. Antoniego Lewka w 2010 roku na Uniwersytecie Kardynała Stefana Wyszyńskiego w Warszawie nie ma znanego w Polsce homilety.

Po śmierci ks. doc. Brzozowskiego 29 listopada 1991 roku przez kilka lat, od 1991 roku do 1994 roku, kuratorem Katedry Homiletyki na KUL był ks. Józef Kudasiewicz (1926-2012)3. Następnie w latach 1996-2012 Katedrą Homiletyki kierował ks. prof. dr hab. Władysław Głowa (ur. 1940), a po nim ks. prof. dr hab. Stanisław Dyk, który od 2009 roku zarządzał

2 Por. J. Mieczkowski, Krakowski Instytut Liturgiczny, s. 243-244; W. Przyczyna, G. Siwek, Krakowska Szkoła Kaznodziejów jako odpowiedź na wyzwania czasów, s. 537-544; H. Sławiński, Powstanie i rozwój Katedry Komunikacji Religijnej PAT, s. 833-843.

3 Dziekanat Wydziału Teologii 20 czerwca 1994 zwolnił ks. prof. dr. hab. Józefa Kudasiewicza z obowiązków kuratora Katedry Homiletyki i powierzył je ks. prof. dr. hab. Anzelmowi Weissowi. Za zgodność: kancelaria rektorska, Lublin, 21 września 1994. 
Katedrą Homiletyki Materialnej, przemienioną w 2014 roku na Katedrę Homiletyki. Ksiądz Kudasiewicz promował biblijno-kerygmatyczny nurt w homiletyce, ks. Głowa, jako liturgista, eksponował liturgię jako źródło i miejsce przepowiadania, a ks. Dyk podejmuje przede wszystkim zagadnienia kerygmatyczno-liturgiczne i ewangelizacyjne, a ponadto zajmuje się homiletyką materialną.

Warto jeszcze zauważyć, że w ostatnich latach wyłania się w Polsce ośrodek homiletyczny w Poznaniu w ramach Uniwersytetu im. Adama Mickiewicza. Kierownikiem Katedry Homiletyki jest ks. dr hab. Adam Kalbarczyk, prof. UAM, prodziekan tamtejszego Wydziału Teologicznego. Wspiera go inny homileta, dr hab. Maciej Szczepaniak, sekretarz abp. Stanisława Gądeckiego. Ponadto w Poznaniu wydawane jest czasopismo z pomocami kaznodziejskimi o ponadstuletniej tradycji, „Biblioteka Kaznodziejska". Poza wymienionymi ośrodkami są jeszcze inne wydziały teologiczne, na których pracują pojedynczy homileci, na przykład w Katowicach, Szczecinie, Opolu.

\section{Homiletyka akademicka w Krakowie}

Począwszy od powstania pierwszego uniwersytetu w Bolonii w 1088 roku uczelnie mają swoją strukturę, na którą składają się wydziały, a w nich funkcjonują katedry kierowane przez samodzielnego pracownika naukowe$\mathrm{go}^{4}$. Bywa też tak, że katedry łączą się w instytuty. Zawsze renomowanym uczelniom zależało na tym, by istniał w nich wydział teologiczny. Tak było również w Krakowie. Dlatego 11 stycznia 1397 roku bullą papieża Bonifacego IX Eximiae devotionis affectus na prośbę św. Jadwigi i króla Władysława Jagiełły został powołany Wydział Teologiczny na istniejącym od 1364 roku Uniwersytecie Jagiellońskim w Krakowie. Istniał on przez wiele wieków. Dopiero Rada Ministrów Polskiej Rzeczypospolitej Ludowej 11 sierpnia 1954 roku bez porozumienia z przedstawicielami Kościoła zlikwidowała Wydział Teologiczny na UJ5. Po usunięciu Wydziału Teologicznego z UJ

4 Por. H. Sławiński, Powstanie i rozwój Katedry Komunikacji Religijnej PAT, s. 833.

5 Por. S. Piech, Wpisani w dziedzictwo nauki, w: Złota księga Papieskiej Akademii Teologicznej, red. S. Piech, Kraków 2000, s. 13. 
Watykańska Kongregacja Seminariów i Studiów Uniwersyteckich 16 grudnia 1959 roku uznała, że:

Wydział Teologiczny zgodnie z jego ustanowieniem i charakterem trwa pod kierownictwem jednej władzy kościelnej i na przyszłość ma się kształtować wedle praw ustanowionych przez Stolicę Apostolską

Po usunięciu z Uniwersytetu Jagiellońskiego Wydział Teologiczny w Krakowie działał w ramach Metropolitalnego Seminarium Duchownego, a wskutek zabiegów kardynała Karola Wojtyły w 1974 roku zyskał miano papieskiego. To właśnie $\mathrm{w}$ ramach tego wydziału zaczął działać od 1968 roku Instytut Liturgiczny, a od 1975 roku także Instytut Teologii Rodziny, powołany przez kardynała Wojtyłę w 1969 roku w strukturach kurii metropolitalnej. Papież Jan Paweł II 8 grudnia 1981 roku na mocy motu proprio Beata Hedvigis ustanowił Papieską Akademię Teologiczną w Krakowie, składającą się z Wydziału Teologicznego oraz Wydziału Filozoficznego i Wydziału Historii Kościoła7. Na mocy dekretu Kongregacji ds. Edukacji Katolickiej 19 czerwca 2009 roku akademia została przekształcona w Uniwersytet Papieski Jana Pawła II w Krakowie.

\subsection{Katedra Homiletyki na Wydziale Teologicznym w Krakowie}

Od kiedy opat benedyktyński Franz Stephan Rautenstrauch (1734-1785) zaliczył w 1774 roku homiletykę do teologii pastoralnej jako nową dyscyplinę w obrębie teologii wykładanej na Uniwersytecie Wiedeńskim, zyskała ona status dyscypliny naukowej ${ }^{8}$. Homiletykę będącą dyscypliną teologiczną wykładano także w Krakowie, uznawszy ją za przedmiot istotny w formacji do kapłaństwa, ale bezpośrednio po soborze watykańskim II

6 Cyt. za: S. Piech, Wpisani w dziedzictwo nauki, s. 45.

7 Por. S. Piech, Wpisani w dziedzictwo nauki, s. 46.

8 Por. B. Mierzwiński, Teologia pastoralna czy teologia praktyczna. Spór o nazwę czy o koncepcje?, "Ateneum Kapłańskie" 2005 t. 144, nr 576, s. 224-233; R. Kamiński, Wprowadzenie do teologii pastoralnej, w Teologia pastoralna, t. 1, Teologia pastoralna fundamentalna, red. R. Kamiński, Lublin 2000, s. 27-29; H. Sławiński, Homiletyka w dobie nowej ewangelizacji, „Acta Facultatis Theologicae Universitatis Comenianae Bratislaviensis" 8 (2011) cislo 2, s. 12-26. 
nie była ona włączona w struktury Wydziału Teologicznego. W tym czasie homiletykę w Metropolitalnym Seminarium Duchownym w Krakowie wykładali: ks. Franciszek Macharski (1927-2016) (wykładał teologię pastoralną i homiletykę w latach 1962-1978), ks. Wacław Świerzawski (1927-2017), ks. Edward Staniek (1941-), ks. dr Tadeusz Olszański (1921-1995). Nie było jednak wówczas katedry homiletyki kierowanej przez samodzielnego pracownika naukowego. Był jedynie jej opiekun. Kuratorem Katedry Homiletyki na Papieskiej Akademii Teologicznej w Krakowie był od 1975 roku dyrektor IL ks. prof. Wacław Świerzawski, będący zarazem kierownikiem Katedry Teologii Liturgii, ale faktycznym opiekunem Katedry Homiletyki został patrolog ks. dr Edward Staniek.

Katedra Homiletyki zaczęła więc funkcjonować w 1975 roku w ramach Wydziału Teologicznego. Do 1986 roku był za nią odpowiedzialny ks. prof. Wacław Świerzawski. Następnie, po obronie pracy habilitacyjnej w 1984 roku, kuratorem Katedry Homiletyki Wydziału Teologicznego PAT był w latach 1986-1997 ks. doc. dr hab. Edward Staniek, który kierował Katedrą Patrologii i Historii Dogmatu.

Ksiądz docent doktor habilitowany Edward Staniek specjalizował się wprawdzie w patrologii, ale z zamiłowania zajmował się także homiletyką. Wykładał ją i 11 lat kierował Katedrą Homiletyki. Wypromował w tym czasie takich znamienitych doktorów homiletyki jak bp Józef Guzdek, ks. Kazimierz Panuś, ks. Franciszek Ślusarczyk, ks. Tadeusz Mrowiec, ks. Jan Nowak, o. Stanisław Kałdon, o. Stanisław Obirek, o. Ryszard Wróbel. Dzieła ks. Stańka zostały przetłumaczone na język łotewski, czeski, ukraiński i białoruski, a krakowskie Wydawnictwo M podjęło się całościowego wydania jego dzieł zebranych. Gdy w 2003 roku powstał Komitet Nauk Teologicznych przy Polskiej Akademii Nauk, do jego grona z największą liczbą głosów oddanych w różnych uczelniach teologicznych w Polsce wybrano krakowskiego patrologa9.

Księdza docenta Stańka od samego początku, to jest od 1986 roku, wspierał w pracy - początkowo jako asystent - ks. Kazimierz Panuś (1955- ), który w 1986 roku obronił licencjat, w 1989 roku doktorat, a w 1997 roku

9 Por. K. Panuś, Laudacja z okazji wręczenia ks. dr. hab. Edwardowi Stańkowi, prof. Papieskiej Akademii Teologicznej w Krakowie, medalu Bene Merenti Polskiego Towarzystwa Teologicznego w Krakowie, http://ptt.net.pl/about/view/8/ks-dr-hab-Edward-Staniek (19.10.2018). 
habilitację, po czym w październiku 1997 roku został faktycznym kierownikiem Katedry Homiletyki na Wydziale Teologicznym PAT. Pełni tę funkcję przez ponad 20 lat do tej pory. Początkowo katedra ta funkcjonowała w ramach wydziału niezależnie od Instytutu Liturgicznego. Została formalnie włączona do jego struktury w roku akademickim 2014/2015. Wówczas wszystkie katedry Wydziału Teologicznego zostały połączone w siedmiu instytutach: liturgicznym, nauk biblijnych, teologii dogmatycznej, teologii duchowości, teologii fundamentalnej, ekumenii i dialogu, teologii moralnej i teologii praktycznej.

Na strukturę organizacyjną samego Instytutu Liturgicznego składają się cztery katedry: Katedra Teologii Liturgii, Katedra Historii Liturgii, Katedra Homiletyki i Katedra Komunikacji Religijnej. Radę Instytutu Liturgicznego tworzy ośmioro pracowników, czterech homiletów i czworo liturgistów: ks. prof. dr hab. Wiesław Przyczyna, ks. prof. dr hab. Kazimierz Panuś, ks. dr hab. Henryk Sławiński, prof. UPJPII, ks. dr hab. Witold Ostafiński, s. dr hab. Adelajda Sielepin, prof. UPJPII, ks. dr hab. Przemysław Nowakowski, prof. UPJPII, ks. dr hab. Janusz Mieczkowski, ks. dr hab. Jarosław Superson. Rada Instytutu Liturgicznego kieruje się regulaminem, który został przyjęty przez Radę Wydziału 24 kwietnia 2015 roku i zatwierdzony przez Senat Uniwersytetu Papieskiego Jana Pawła II w Krakowie 18 maja 2015 roku.

\subsection{Studium Homiletyczne w Krakowie}

Paralelnie do Katedry Homiletyki na Wydziale Teologicznym Papieskiej Akademii Teologicznej w Krakowie zajęcia naukowo-badawcze i dydaktyczne w zakresie homiletyki były prowadzone w Studium Homiletycznym włączonym do Wydziału Teologicznego PAT. Zostało ono utworzone dzięki staraniom o. dr. Gerarda Siwka (1938-2015) decyzją Rady Wydziału Teologicznego PAT z 22 kwietnia 1988 roku, początkowo ad experimentum na dwa lata począwszy od października 1988 roku. Było ono pomyślane jako studium podyplomowe stawiające sobie za cel pomoc duszpasterzom diecezjalnym i zakonnym w skuteczniejszym wypełnianiu posługi słowa ${ }^{10}$.

10 Powstanie Studium Homiletycznego było spełnieniem oczekiwań ojców redemptorystów, którzy w swej warszawskiej prowincji mieli zakonną szkołę kaznodziejską zwaną 
Jego pierwszym kierownikiem był redemptorysta o. dr Gerard Siwek ${ }^{11}$. Wspomagał go o. Wiesław Przyczyna (1953-), który po uzyskaniu doktoratu w 1989 roku sam został kierownikiem Studium Homiletycznego. Kierował nim od 1990 do 2009 roku.

Eksperyment sprawdził się w praktyce, a studium rozwijało się i poszerzało swą ofertę programową. Staraniem o. dr. Wiesława Przyczyny 17 października 1996 roku podpisana została umowa na trzy lata o współpracy między dyrektorem Instytutu Liturgicznego PAT ks. prof. dr. hab. Wa-

Tirocinium Pastorale. Przygotowywała ona absolwentów do prowadzenia misji i rekolekcji, czego wymagały zarówno reguły zakonu, jak i konstytucja apostolska Piusa XII Sedes sapientiae (31.05.1956). W 1983 siedziba Tirocinium została przeniesiona z Torunia do Krakowa. Dnia 1.03.1987 Nadzwyczajna Rada Prowincji Warszawskiej Ojców Redemptorystów zadecydowała o podjęciu starań o związanie Tirocinium z Papieską Akademią Teologiczną w Krakowie, a do prowadzenia rozmów wydelegowano ówczesnego prefekta Tirocinium dr. Gerarda Siwka CSsR. Jego interlokutorami ze strony PAT byli ks. Wacław Świerzawski i ks. Edward Staniek. Potrzebę powołania Studium Homiletycznego jako sekcji w ramach Wydziału Teologicznego argumentowano następująco: „,motywem powołania do istnienia sekcji jest pragnienie służenia pomocą duchowieństwu (zwłaszcza młodszemu) w owocniejszym spełnianiu posługi słowa. Posługa ta staje się coraz trudniejsza z powodu wzrastających wymagań wiernych oraz pojawiających się coraz to nowych barier, utrudniających skuteczne porozumienie się kaznodziei ze słuchaczami. Nieumiejętność radzenia sobie z tymi trudnościami sprawia, że pomimo tak obfitego posiewu słowa kryzys wiary nie tylko trwa, ale daje się wzrastać. Celem sekcji jest kształtowanie dojrzałych osobowości kaznodziejskich, zdolnych do owocnego spełniania powierzonego im zadania przez kontynuację i pogłębianie wyniesionej z seminarium formacji duchowej, intelektualnej i pastoralnej. Cechą charakterystyczną sekcji jest mocne zaakcentowanie aspektu praktycznego (opracowywanie kazań) oraz umożliwienie (rok II) specjalizacji z zakresu nieco zaniedbanego dziś kaznodziejstwa seryjnego głównie misyjno-rekolekcyjnego. W ten sposób sekcja, nie zaniedbując pracy intelektualno-badawczej, staje się swego rodzaju szkołą kaznodziejską". Ustalono wówczas, że homiletyka nie będzie stanowić samodzielnej sekcji Instytutu Liturgicznego, lecz zostanie włączona jako podsekcja do Sekcji Teologicznej-Archiwum Studium Homiletycznego; także: J. Mieczkowski, Krakowski Instytut Liturgiczny, s. 243-244.

11 Por. W. Skworc, Stowo biskupa tarnowskiego, w: Stuchacz słowa, red. W. Przyczyna, Kraków 1998, s. 10; W. Przyczyna, Życie i działalność ojca doktora Gerarda Siwka CSsR, w: Stuchacz słowa, s. 17 . 
cławem Świerzawskim a dyrektorem Instytutu Filologii Polskiej UJ prof. dr. hab. Andrzejem Borowskim. Umowę tę po trzech latach owocnej współpracy przedłużono na czas nieokreślony 17 października 1999 roku. Na jej mocy studenci Podyplomowego Studium Homiletycznego mogli kształcić się w zakresie homiletyki formalnej, korzystając z oferty Podyplomowego Studium Retoryki, które powstało w 1995 roku w Instytucie Filologii Polskiej UJ, istniejącym dziś pod nazwą Wydziału Polonistyki ${ }^{12}$. Podyplomowe Studium Homiletyczne było wówczas określane popularnie jako „krakowska szkoła kaznodziejów”, nauka w nim trwała dwa lata i była opłacana przez studentów. Zajęcia prowadzono w systemie zaocznym, to znaczy podczas 15 sesji zjazdowych $\mathrm{w}$ roku akademickim, i odbywały się one w czwartki, piątki i soboty do południa ${ }^{13}$.

W latach 1995-2005 bywało tak, że w Studium Homiletycznym uczestniczyło 20-30 osób na roku, a były dwa roczniki liczące razem 40-6o osób. W pierwszej dekadzie istnienia studium ukończyło je około dwustu księży. Popularność studium w owym czasie wynikała po części z tego faktu, że księża uczący religii w szkole starali się o awans zawodowy: od stażysty przez nauczyciela kontraktowego, mianowanego aż po dyplomowanego. Uzyskanie dyplomu Studium Homiletyki PAT było respektowane i pomagało w ścieżce awansu zawodowego.

\subsection{Katedra Komunikacji Religijnej na PAT (UPJPII)}

Ważnym etapem w rozwoju Studium Homiletyki stała się od 2002 roku oferta studiów dziennych licencjacko-doktoranckich w zakresie homiletyki w IL PAT. Po uzyskaniu habilitacji w 2001 roku o. Wiesław Przyczyna uzyskał zgodę Rady Wydziału Teologicznego UPJPII na utworzenie w 2002 roku Katedry Komunikacji Religijnej, której został kierownikiem. Od tamtej pory studia licencjackie trwają dwa lata, a studia doktoranckie najpierw trwały dwa lata, a obecnie rok. Opcjonalny rok czwarty służy dokończeniu pracy doktorskiej i nie wiąże się z udziałem w zajęciach wykładowych.

\footnotetext{
12 Por. J. Mieczkowski, Krakowski Instytut Liturgiczny, s. 250-251.

13 Por. W. Przyczyna, G. Siwek, Krakowska Szkoła Kaznodziejów jako odpowiedź na wyzwania czasów, s. 540-541.
} 
Od roku akademickiego 2007/2008 studia licencjacko-doktoranckie z homiletyki zostały ściśle zsynchronizowane ze studiami dla studentów teologii liturgii i katechumenatu. Ponieważ Katedra Komunikacji Religijnej działa w ramach Instytutu Liturgicznego, studenci uczestniczą zarówno w zajęciach z teologii liturgicznej, jak i homiletycznej. Mają też możliwość indywidualnego wyboru części zajęć monograficznych spośród obfitej oferty Wydziału Teologicznego.

Pierwszym i głównym celem Katedry Komunikacji Religijnej jest prowadzenie badań w dziedzinie komunikacji religijnej ze szczególnym uwzględnieniem przepowiadania słowa Bożego i komunikacji duszpasterskiej w Kościele katolickim. Badania dotyczą więc zarówno komunikacji podczas liturgii, jak i poza celebracjami liturgicznymi. Drugim ważnym celem katedry jest kształcenie studentów w zakresie przepowiadania słowa Bożego i nowoczesnych środków komunikacji, w tym religijnej, oraz rozbudzanie w nich świadomości priorytetowej roli przepowiadania słowa w posłudze Kościoła działającego zawsze w określonym środowisku kulturowym. Wreszcie trzecim celem katedry jest przygotowywanie przyszłych wykładowców homiletyki. Katedra Komunikacji Religijnej jest więc odpowiedzialna za homiletykę akademicka, to znaczy za studia prowadzące do uzyskania licencjatu teologicznego i doktoratu z teologii ze specjalizacją w zakresie homiletyki.

Kierownikiem Katedry Komunikacji Religijnej jest nieprzerwanie od 2002 roku ks. prof. dr hab. Wiesław Przyczyna. Wspiera go ks. dr hab. Henryk Sławiński, prof. UPJPII, który w roku akademickim 2002/2003 prowadził zajęcia zlecone z komunikacji kaznodziejskiej, a od października 2004 roku, po roku urlopu naukowego spędzonego w Niemczech, jest etatowym pracownikiem w Katedrze Komunikacji Religijnej na Wydziale Teologicznym UPJPII w Krakowie. Wcześniej, do końca 2003 roku, czyli do ukończenia 65 roku życia, etatowym pracownikiem katedry był o. dr hab. Gerard Siwek. Ponadto pracę katedry od 2009 roku wspomaga zatrudniony od 2008 roku na Wydziale Teologicznym UPJPII ks. dr hab. Witold Ostafiński, adiunkt w Katedrze Homiletyki, a jak trzeba, to także ks. prof. Kazimierz Panuś, kierownik Katedry Homiletyki.

Siedziba katedry znajdowała się najpierw w klasztorze oo. Redemptorystów przy ul. Zamojskiego 56, następnie przy ul. Szujskiego 4, a obecnie w placówce dydaktycznej UPJPII przy ul. Bernardyńskiej 3. Kolejno w tych też miejscach $\mathrm{w}$ minionych latach odbywały się zajęcia dla studentów. 
Od października 1988 roku do końca roku akademickiego 2004/2005 zajęcia odbywały się w budynku przy ul. Zamojskiego 56, od roku 2005/2006 w budynku przy ul. Szujskiego 4, a od 2013/2014 do tej pory zajęcia odbywają się w głównym budynku dydaktycznym UPJPII przy ul. Bernardyńskiej 3 .

\section{Działalność badawcza i pisarska homiletów Instytutu Liturgicznego w Krakowie}

Jak wspomniano, głównym celem katedr na Wydziale Teologicznym jest prowadzenie prac badawczych, których owocem są publikacje przedstawione poniżej. Toteż homileci z Instytutu Liturgicznego podejmują działalność badawczą i pisarska, która nadaje specyficzny profil każdemu z pracowników.

\subsection{Obszary badań homiletów Instytutu Liturgicznego w Krakowie}

Gerard Siwek CSsR opublikował następujące monografie, które wskazują na zagadnienia, jakimi się zajmował w swej pracy badawczej: Misje ludowe w teorii i praktyce Kościoła (1999); Blaski i cienie wspótczesnego przepowiadania (2007); Rekolekcje wczoraj i dziś (2011); Osobowość kaznodziei dzisiaj (2014). Trzeba dopowiedzieć, iż Gerard Siwek ma w swym dorobku także kilka tomów z tekstami homilii i kazań. Wiesław Przyczyna zajmuje się przede wszystkim takimi zagadnieniami jak ewangelizacja, Biblia w przepowiadaniu, język religijny, przepowiadanie i liturgia, metodologia teologii pastoralnej, posoborowa homilia. Opublikował następujące monografie autorskie: Teologia ewangelizacji (1992); Kaznodziejski przekaz opowiadań biblijnych (2000); Homilia pięćdziesiąt lat po Soborze Watykańskim II. Pytania, problemy, wyzwania (2013).

Obszarem badań Kazimierza Panusia jest historia kaznodziejstwa, sztuka głoszenia kazań, hagiografia, a ostatnio także edytorstwo kazań polskich. Ma w swym dorobku następujące książki: Kaznodziejstwo w katedrze krakowskiej, cz. 1-2 (1995); Uratować naród! Głos z ambony katedry wawelskiej okresu niewoli narodowej 1975-1918 (1996); Zarys historii kaznodziejstwa w Kościele katolickim (1999-2001); Święty Marcin z Tours (2003); Wielcy mówcy Kościoła (2004); Święty Patryk (2004); Wielcy mówcy Kościoła w Polsce (2005); Henryk Lacordaire (2005); Święty Leon Wielki (2005); Wielcy kaznodzieje Krakowa (2006); Święty Jan Vianney (2006); Piotr Skarga (2006); Historia kaznodziejstwa (2007); 
Wielcy mówcy katedry na Wawelu (2008); Sztuka głoszenia kazań (2008); Błogostawiony Edmund Bojanowski (2009).

Henryk Sławiński zajmuje się w swych badaniach homiletyką amerykańską, teologią homilii, przepowiadaniem pasyjnym, językiem przepowiadania, kulturowymi uwarunkowaniami przepowiadania, głoszeniem słowa Bożego i nowoczesną technologią oraz pedagogiką chrześcijańską. Opublikował monografie: Przepowiadanie Chrystusowego krzyża (1997); Wychowanie prorodzinne. Wedtug pedagogów katolickich Drugiej Rzeczypospolitej (2000); Znak zwycięstwa. Symbolika krzyża w liturgii sakramentów świętych (2001); "Dziś spetnity się słowa Pisma, któreście styszeli". Homilia w niedzielnym zgromadzeniu wiernych (2002); Między ciagłościa a zmiana. Teoria homilii w Stanach Zjednoczonych po II Soborze Watykańskim (2008); Homilia niedzielna. Dokumenty Konferencji Episkopatu Stanów Zjednoczonych (2015); Homilia w zgromadzeniu eucharystycznym. Recepcja wspótczesnego nauczania Kościoła w „Dyrektorium homiletycznym" (2018). Oprócz monografii naukowych Henryk Sławiński wydał sześć tomów homilii na niedziele i uroczystości w roku liturgicznym (Wydawnictwo WAM 2007-2009; Wydawnictwo Salwator 2013-2015).

Z kolei Witold Ostafiński, adiunkt w Katedrze Homiletyki, prowadzi badania naukowe z zakresu homiletyki, retoryki, komunikacji międzyludzkiej, a szczególnie języka perswazji i sztuki wystąpień publicznych. Bada zagadnienia efektywnego komunikowania, interakcji w przekazie werbalnym i niewerbalnym. Podejmuje także zagadnienia polskiej kultury i europejskiej kultury oraz ich wpływu na przepowiadanie. Opublikował monografię: Wstęp w teorii i praktyce kaznodziejskiej. Studium homiletyczno-retoryczne (2002), a także krytyczną edycję kazań abp. Józefa Michalika, wieloletniego przewodniczącego Konferencji Episkopatu Polski.

\subsection{Serie wydawnicze}

Homileci krakowscy redagują kilka serii wydawniczych. Najstarszą i najobszerniejszą jest Redemptoris Missio.

\subsubsection{Redemptoris Missio}

Seria Redemptoris Missio wydawana jest od 1991 roku, początkowo pod redakcją Gerarda Siwka (1991-2001), a następnie Wiesława Przyczyny. W jej ramach ukazały się 34 tomy podejmujące zagadnienia z teorii homiletycznej, a także pomoce kaznodziejskie: W drodze na ambonę, red. G. Siwek 
(1991); W. Przyczyna, Teologia ewangelizacji (1992); G. Siwek, Przepowiadać skuteczniej. Elementy retoryki kaznodziejskiej (1992); Rekolekcje dla młodzieży, red. W. Przyczyna (1993); Z zagadnień współczesnej homiletyki, red. W. Przyczyna (1993); Fenomen kazania, red. W. Przyczyna (1994); G. Siwek, Rekolekcje dla dorostych (1994); R. Zerfass, Od aforyzmu do kazania (1995); R. Zerfass, Od perykopy do homilii (1995); Rekolekcje dla dzieci, red. W. Przyczyna (1996); D. Zdunkiewicz-Jedynak, Językowe środki perswazji w kazaniu (1996); Stuga Stowa, red. W. Przyczyna (1997); G. Siwek, Homilie obrzędowe (1997); A. Baczyński, Telewizja w służbie ewangelizacji (1998); Stuchacz Słowa, red. W. Przyczyna (1998); Trzymajcie się mocno Stowa Życia. Rekolekcje dla młodzieży, red. W. Przyczyna, G. Siwek (1999); G. Siwek, Misje ludowe w teorii i praktyce Kościoła (1999); W. Przyczyna, Kaznodziejski przekaz opowiadań biblijnych (2000); G. Siwek, Kazania maryjne (2001); Retoryka dziś. Teoria i praktyka, red. R. Przybylska, W. Przyczyna (2001); Prawdy wiary w przepowiadaniu, red. W. Przyczyna (2002); K. Müller, Homiletyka na trudne czasy (2003); Retoryka na ambonie. Z problemów wspótczesnego kaznodziejstwa, red. P. Urbański (2003); Msza Święta w telewizji?, red. W. Przyczyna (2006); G. Siwek, Blaski i cienie wspótczesnego przepowiadania (2007); Polska bibliografia homiletyczna 1945-2005, oprac. W. Przyczyna, L. Szewczyk (2007); Ściagać czy nie ściagać? O pomocach do homilii i kazań, red. M. K. Kubiak, W. Przyczyna (2008); H. Sławiński, Między ciagłością a zmiana. Teoria homilii w Stanach Zjednoczonych po II Soborze Watykańskim (2008); Liturgia i przepowiadanie, red. W. Przyczyna (2010); G. Siwek, Rekolekcje wczoraj i dziś (2011); Metodologia teologii praktycznej, red. W. Przyczyna (2011); W. Przyczyna, Homilia piećdziesiąt lat po Soborze Watykańskim II. Pytania, problemy, wyzwania (2013); Polityka na ambonie?, red. W. Przyczyna, L. Szewczyk (2015); Stowo, obraz, dźwięk w mszach świętych z udziałem dzieci, red. H. Sławiński, W. Przyczyna (2019).

\subsubsection{Teolingwistyka}

Inną serią wydawniczą redagowaną przez Wiesława Przyczynę jest Teolingwistyka. Ukazało się w niej 14 tomów: Zasady pisowni słownictwa religijnego, red. R. Przybylska, W. Przyczyna (2004); D. Zdunkiewicz-Jedynak, Surfując po Internecie w poszukiwaniu Boga (2006); Świat słowa Jana Pawła II, oprac. M. Dalgiewicz (2007); Bibliografia języka religijnego 1945-2005, oprac. M. Makuchowska (2007); Jezzyk katechezy, red. R. Przybylska, W. Przyczyna (2008); Polszczyzna biblijna - między tradycja a wspótczesnościa, t. 1-2, red. S. Koziara, W. Przyczyna (2009); A. Gomola, Bóg 
kobiet. Studium językoznawczo-teologiczne (2010); Dyskurs religijny w mediach, red. D. Zdunkiewicz-Jedynak (2010); M. Wojtak, Wspótczesne modlitewniki wobec przeobrażeń dyskursu religijnego (2011); R. Przybylska, W. Przyczyna, Pisownia słownictwa religijnego (2011); Funkcje wypowiedzi religijnych, red. R. Przybylska, W. Przyczyna (2014); I. Rutkowska, Niepojęty świat duszy. Język doświadczeń mistycznych św. Faustyny Kowalskiej (2017); Nowa ewangelizacja. Język - teologia - kultura, red. M. Nowak, W. Przyczyna (2017); Język w liturgii, red. B. Drabik, W. Przyczyna (2018).

\subsubsection{Wielcy Mówcy Kościoła}

Kazimierz Panuś redaguje serię wydawniczą Wielcy Mówcy Kościoła, w której od 2004 roku ukazało się pięć tomów: K. Panuś, Wielcy mówcy Kościoła (2004); K. Panuś, Wielcy mówcy Kościoła w Polsce (2005); Wielcy kaznodzieje Krakowa. Studia in honorem Eduardi Staniek, red. K. Panuś (2006); E. Staniek, Wielcy mówcy Kościoła staroży tnego (2007); K. Panuś, Wielcy mówcy katedry na Wawelu (2008).

\subsubsection{Kazania w Kulturze Polskiej}

Druga seria wydawnicza redagowana przez Kazimierza Panusia jest zatytułowana Kazania w Kulturze Polskiej. Edycje Kolekcji Tematycznych. Ukazały się w niej dotychczas trzy tomy: Kazania maryjne, oprac. R. Mazurkiewicz, K. Panuś (2014); Kazania funeralne, oprac. K. Panuś, M. Skwara (2014); Kazania pasyjne, oprac. J. Gruchała, K. Panuś (2014). Te trzy obszerne, sześciusetstronicowe antologie każda zawierają reprezentatywne kazania polskie od XIV do XXI wieku. Trzeba zauważyć, że seria ta została przygotowana w ramach Narodowego Programu Rozwoju Humanistyki (NPRH) w latach 2012-2014 i wyróżniona jako Książka Roku 2014 w konkursie Komitetu Nauk Teologicznych Polskiej Akademii Nauk, a także nagrodzona wyróżnieniem Stowarzyszenia Wydawców Katolickich Feniks 2015.

\subsubsection{Ancilla Verbi}

Henryk Sławiński redaguje serię wydawniczą Ancilla Verbi, w której od 2001 roku ukazało się siedem tomów: H. Sławiński, Znak zwycięstwa. Symbolika krzyża w liturgii sakramentów świętych (2001); Komisja ds. Życia i Posługi Kapłanów przy Krajowej Konferencji Biskupów Katolickich USA, "Dziś spetnity się słowa Pisma, któreście styszeli". Homilia w niedzielnym zgromadzeniu wiernych, przekład i wprowadzenie H. Sławiński (2002); Homilia 
niedzielna. Dokumenty Konferencji Episkopatu Stanów Zjednoczonych, przekład, opracowanie i redakcja H. Sławiński (2015); Głosimy Pana Jezusa Chrystusa. Treść przepowiadania, red. H. Sławiński (2017); T. Krzesik OMI, Problematyka czyśćca w polskim przepowiadaniu po Soborze Watykańskim II (2017); A. Cygański, Dialogiczny wymiar homilii po Soborze Watykańskim II (2018); H. Sławiński, Homilia w zgromadzeniu eucharystycznym. Recepcja wspótczesnego nauczania Kościoła w "Dyrektorium homiletycznym” (2018).

\subsection{Publikacje homiletów krakowskiego Instytutu Liturgicznego w Bibliografii homiletycznej}

Podając stan polskiej Bibliografii homiletycznej w listopadzie 2016 roku, ks. prof. Leszek Szewczyk zaznaczył, że znalazły się w niej publikacje 1406 autorów, przy czym ponad połowę spośród nich stanowią autorzy prac magisterskich. Zauważył także, że do najbardziej aktywnych pisarsko homiletów, których prace odnotowano we wspomnianej bibliografii, należą: Kazimierz Panuś (233 pozycje), Gerard Siwek (198 pozycji), Jan Twardy (175 pozycji), Wiesław Przyczyna (156 pozycji), Henryk Sławiński (132 pozycje), Antoni Lewek (98 pozycji), Stanisław Dyk (8o pozycji), Leszek Szewczyk (79 pozycji), Waldemar Wojdecki (49 pozycji), Herbert Simon (46 pozycji), Mieczysław Brzozowski (42 pozycje), Wojciech Pazera (42 pozycje), Andrzej Draguła (36 pozycji), Broński Włodzimierz (34 pozycje), Tadeusz Lewandowski (33 pozycje), Marian Rzeszewski (32 pozycje), Adam Kalbarczyk (30 pozycji) i Leszek Kuc (29 pozycji) ${ }^{14}$. To znaczy, że pierwszą piątkę, poza ks. prof. Janem Twardym z Przemyśla, tworzą homileci z Krakowa. Trudno nie zauważyć tego potencjału homiletycznego.

\section{Działalność dydaktyczna homiletów Instytutu Liturgicznego w Krakowie}

Kolejnym, obok prac badawczych, celem Katedry Komunikacji Religijnej i Katedry Homiletyki jest systematyczna praca dydaktyczna, czyli

14 Por. L. Szewczyk, Kierunki badań w homiletyce polskiej na podstawie zawartości „Bibliografii homiletycznej”, „Polonia Sacra” 21 (2017) nr 2 (47), s. 48. 
kształcenie studentów w zakresie przepowiadania słowa Bożego oraz przygotowanie wykładowców homiletyki. Od kilku lat wykłady prowadzone z katolickiego punktu widzenia wzbogacane są przez wykłady i ćwiczenia z perspektywy innych wyznań chrześcijańskich i judaizmu.

Oferta studiów licencjacko-doktoranckich adresowana jest do absolwentów teologii, którzy uzyskali wcześniej tytuł zawodowy magistra teologii. Niemniej jednak jest też część wykładów monograficznych oferowana słuchaczom ze studiów pierwszego i drugiego stopnia. Wykładowcami są pracownicy Uniwersytetu Papieskiego Jana Pawła II w Krakowie oraz zaproszeni wykładowcy z innych uczelni oraz z innych wspólnot chrześcijańskich i wspólnoty żydowskiej ${ }^{15}$.

\subsection{Zajęcia dydaktyczne}

Zajęcia dydaktyczne z homiletyki akademickiej odbywały się lub nadal się odbywają w postaci wykładów, ćwiczeń, konwersatoriów, e-learningu i seminarium naukowego. Oprócz przeważającej oferty w języku polskim od roku akademickiego 2011/2012 co roku są przeprowadzane zajęcia także w języku angielskim. Zajęcia odbywają się w środy i czwartki każdego tygodnia w ciągu roku akademickiego.

W latach działalności Katedry Komunikacji Religijnej studenci mogli uczestniczyć w następujących wykładach w języku polskim: Obrzędy sakramentu chrztu źródłem przepowiadania; Słowo Boże podczas obrzędów pierwszej spowiedzi i komunii świętej; Przepowiadanie w Eucharystii; Przepowiadanie podczas sakramentu matżeństwa; Przepowiadanie sakramentalne; Przepowiadanie a sakramentalia; Przepowiadanie pogrzebowe; Rekolekcje parafialne w kontekście roku liturgicznego; Przepowiadanie rekolekcyjne; Kaznodziejstwo misyjne; Przepowiadanie pasyjne; Od liturgii synagogalnej do chrześcijańskiej; Przepowiadanie słowa Bożego wobec wyzwań współczesności; Problemy współczesnego przepowiadania; Kulturowe i społeczne uwarunkowania przepowiadania słowa Bożego; Stuchacz stowa Bożego; Homilia po II Soborze Watykańskim; Sztuka publicznego przemawiania; Ars docendi (wykład obowiązkowy dla studentów Wydziału Teologicznego).

15 Por. http://il.wt.upjp2.edu.pl/index.php/tekstowa/1173/ (22.10.2018). 
Natomiast w języku angielskim proponowane były następujące wykłady prowadzone przez Henryka Sławińskiego: Evangelization - Essential Task of the Church; The Word of God in the Pastoral Care of the Church; Preaching the Word of God in the Context of Contemporary Challenges; Preaching the Word of God to the Contemporary World.

\subsection{Sylwetka absolwenta}

Słuchaczami zajęć akademickich z homiletyki są przede wszystkim księża pochodzący z różnych diecezji i zgromadzeń zakonnych, ale są to też siostry zakonne i osoby świeckie. Przeważają studenci z różnych regionów Polski, między innymi z Zielonej Góry, Gdańska, Gdyni, Ełku, Białegostoku, Warszawy, Bydgoszczy, Poznania, Kalisza, Włocławka, Łowicza oraz wielu miejscowości Polski południowej. Jednak oprócz nich była lub nadal jest część studentów ze Stanów Zjednoczonych, Kanady, Malawi, Niemiec, Litwy, Ukrainy, Białorusi, Słowenii i ze Słowacji.

Absolwent studiów odznacza się: pogłębioną wiedzą na temat głoszenia słowa Bożego w liturgii i poza nią; znajomością przepowiadania słowa Bożego w innych wyznaniach chrześcijańskich i w judaizmie; umiejętnością komunikowania się w przestrzeni liturgicznej, pozaliturgicznej i duszpasterskiej; wrażliwością na kontekst kulturowy głoszenia słowa Bożego i komunikacji religijnej; zdolnością do komunikacji interpersonalnej w pluralistycznym społeczeństwie ${ }^{16}$.

Jednym z ważnych owoców pracy dydaktycznej są wypromowani doktorzy. Wiesław Przyczyna wypromował 3 doktorów, którymi są: Emil Floriš, Włodzimierz Guzik, Hieronim Kosiarski. Kazimierz Panuś wypromował 15 doktorów z różnych diecezji polskich i z różnych zgromadzeń zakonnych. Są nimi: ks. Lesław Juszczyszyn, ks. Marian Wróblewski, ks. Witold Ostafiński, ks. Krzysztof Kida, ks. Stanisław Bąk, ks. Zbigniew Kosik, ks. Andrzej Ślusarz, ks. Maciej Radej, ks. Artur Seweryn, Jarosław Kawa, ks. Dariusz Grelecki, o. Sebastian Wiśniewski, ks. Artur Barański, ks. Stefan Klajman, ks. Jerzy Jastrzębski. Henryk Sławiński wypromował 2 doktorów, którymi są ks. Arkadiusz Cygański i o. Tomasz Krzesik.

16 Por. http://il.wt.upjp2.edu.pl/index.php/tekstowa/1173/ (16.10.2018). 


\section{Działalność organizacyjna i stowarzyszeniowa homiletów Instytutu Liturgicznego w Krakowie}

Trudno w krótkim opracowaniu omówić wieloraką działalność organizacyjną i stowarzyszeniową. Wśród bardzo wielu inicjatyw organizacyjnych warto wymienić I Ogólnopolski Kongres Ewangelizatorów Wędrownych w Krakowie (9-11 października 1997) ${ }^{17}$, konferencję naukową w Krakowie przygotowaną wraz z Instytutem Religioznawstwa UJ pod tytułem Dziedzictwo judaizmu we współczesnej liturgii chrześcijańskiej z udziałem prelegentów z kraju i zagranicy (21 lutego 2006) ${ }^{18}$, konferencję w Poznaniu z okazji setnego jubileuszu czasopisma „Biblioteka Kaznodziejska” (19-20 września 2006) ${ }^{19}$, a także międzynarodową konferencję w s'-Hertogenbosch w Holandii pod tytułem Religious Liberty, Relativism, and Secularisation in Our Modern Societies, and their Implications for the Situation of the Church (21-24 lutego 2015).

Gdy chodzi o działalność stowarzyszeniowa, Wiesław Przyczyna był przewodniczącym Stowarzyszenia Homiletów Polskich (2003-2014) i jest przewodniczącym Zespołu Języka Religijnego Rady Języka Polskiego. Kazimierz Panuś jest od 1996 roku dotychczas prezesem Polskiego Towarzystwa Teologicznego, a Henryk Sławiński jest od 2014 roku dotychczas przewodniczącym Stowarzyszenia Homiletów Polskich.

\section{Zakończenie}

Zarówno jubileusze przeżywane w życiu osobistym, jak i te związane z funkcjonowaniem instytucji społecznych są okazją nie tylko do chwa-

17 Por. H. Sławiński, Pierwszy Ogólnopolski Kongres Ewangelizatorów Wẹdrownych, „Ateneum Kapłańskie" [dalej: AK] 534 (1998) z. 2, s. 287-294.

18 Por. H. Sławiński, Judaistyczne korzenie wspótczesnej homilii, w: Ekumenizm, teologia, kultura, red. K. Konecki, Z. Pawlak, K. Rulka, Włocławek 2006, s. 488-501; H. Sławiński, T. Nowak, Sesja naukowa Dziedzictwo judaizmu we wspótczesnej liturgii chrześsijańskiej, AK 583 (2006) z. 3, s. 599-60o.

19 Por. Sprawozdanie z sympozjum homiletycznego nt. Posługa słowa - posłudze Stowu. Rola pomocy kaznodziejskich w przepowiadaniu słowa Bożego, Poznań, 19-20.09.2006, AK 587 (2007) z. 1, s. $185-188$. 
lebnej autoprezentacji, ale też do refleksji nad przeszłymi zaniedbaniami i przyszłymi wyzwaniami. Refleksja ta powinna być źródłem motywacji do rozwoju. Ważnym postulatem jest zmiana nazwy Instytutu Liturgicznego na Instytut Liturgiczno-Homiletyczny. Takie sformułowanie odpowiadałoby prawdzie i miałoby znaczenie promocyjne. Przynajmniej od Łaby do Władywostoku trudno znaleźć instytut teologiczny, który dysponowałby tak wykształconym personelem $\mathrm{w}$ zakresie homiletyki, jakim może poszczycić się IL w Krakowie.

Nowe wyzwania związane są z przekształceniem szkolnictwa wyższego w Polsce. W związku z nim trzeba będzie większy akcent położyć na pozyskiwanie grantów na badania naukowe z homiletyki oraz współpracę międzyuczelnianą.

\section{Summary}

\section{The Homiletics at the Liturgical Institute. Beginnings and the Deve-} lopment

Rev. dr. habil. Henryk Sławiński delivered the lecture entitled The Homiletics at the Liturgical Institute. Beginnings and the Development. He note that the institutions depend on people, especially in the field of academic teaching it's the illustrious teachers that give the authority to the teaching institution. At the Theological Faculty in Krakow there are following people, who had or still have a say in the field of Homiletics: Edward Staniek, Kazimierz Panuś, Gerard Siwek, Wiesław Przyczyna, Henryk Sławiński, Witold Ostafiński. Homiletics has been taught in Krakow as the necessary subject in the formation of the candidates for priesthood. The Chair of Homiletics was introduced in 1975 under the care of prof. Wacław Świerzawski, and then from 1984 was under the care of Edward Staniek. In 1997 the Chair of Homiletics was conferred to Kazimierz Panuś, responsible for it till the present time.

It was in 1988 that Studies in Homiletics were inaugurated at the academic level under the leadership first of Gerard Siwek, and then Wiesław Przyczyna. The important initiative was inaugurated in 2002: the studies were introduced, which allowed to receive the titles of ecclesiastical licentiate and doctorate in Homiletics. The studies are offered at the Chair of Religious Communication. There are three main purposes of this Chair: theological research in the field of religious commu- 
nication, especially in preaching; formation of students in preaching as the intrinsic mission of the Church; and the preparation of the future teachers of Homiletics. The fruits of the theological research have been published in many papers and books, especially in the homiletical series of books: Redemptoris Missio, Teolingwistyka, Wielcy Mówcy Kościoła, Kazania w Kulturze Polskiej, Ancilla Verbi.

As fare as the students are concerned, they come most of all from Poland, but there were also some from the United States, Canada, Malawi, Germany, Lithuania, Ukraine, Belarus, Slovenia and Slovakia. At least 21 students were promoted to PHD degree in Homiletics.

The importance of the Homiletics in Krakow has been appreciated in Poland, which found its expression in the election of Wiesław Przyczyna (2003-2014), and then Henryk Sławiński (2014- ) as the Presidents of the Society of Polish Teachers of Homiletics. 
